\title{
On the Tensile Behavior of High Density Polyethylene Subjected to Cold Rolling
}

\author{
ROBERT M. CADDELL and THOMAS BATES, Jr. \\ Department of Mechanical Engineering, University of Michigan, Ann Arbor, Mich. (U.S.A.) \\ and
}

GREGORY S. Y. YEH

Departments of Materials and Metallurgical Engineering, and Chemical Engineering, University of Michigan. Ann Arbor, Mich. (U.S.A.)

(Received November 15, 1971)

\section{Summary $y^{\dagger}$}

High density polyethylene was cold rolled to produce a series of specimens having from zero to $50 \%$ cold work. For those worked beyond $20 \%$, the absolute thickness recovery was relatively constant. X-Ray diffraction studies indicated that significant changes in the original structure also occurred in specimens cold worked beyond $20 \%$ and that increasing c-axis orientation was coincident with greater cold work.

From the fully recovered specimens, tensile behavior was studied for two strain rates. The early portions of the true stress-true strain curves vary as the degree of initial cold rolling increases; this is reflected in different values of the elastic modulus which exhibits a minimum with material cold rolled about $25 \%$.

Tensile instability or necking is delayed as the degree of initial cold working increases but little variation was observed in regard to the tensile strength. The findings pertain for both strain rates. Regarding specimens of similar "structural" condition, say for example $15 \%$ cold work, higher strain rates correlate with greater strength and lower strain at instability.

In a qualitative manner, comparative behavior between this polymer and ductile metals is discussed.

\section{INTRODUCTION}

Although the number of studies devoted to the cold forming of polymers by traditional forming

\footnotetext{
${ }^{\dagger}$ For French and German translations of the summary, see p. 229.
}

processes is relatively limited, interest in this aspect of polymer deformation is increasing. One area of concern lies in the change of macroscopic mechanical properties of interest to the engineer. Some of the published works that typify this area of study are by Williams and Ford ${ }^{1,2}$, Broutman et al.$^{3,4}$ and Buckley and Long. Far more effort has been expended by persons whose major interest lies in the "microscopic" approach wherein attempts have been made to explain property behavior in terms of structural changes; this is the regime of the polymer scientist. Examples of these studies would be the works of Hinton and Rider ${ }^{6}$, Imada et al. ${ }^{7}$, Owen and Ward $^{8}$ and Meinel and Peterlin ${ }^{9}$.

The results presented in this present paper have been pursued more from the engineering than the structural point of view; certain limited evidence related to structure is, however, included. Although the effect of cold rolling on the resultant properties of polyethylene had been studied earlier by Rothschild and Maxwell ${ }^{10}$, their findings were very limited. In addition the present work elucidates results and concepts not observed or mentioned in that earlier investigation.

As the primary purpose in this study was not geared to a detailed investigation of the influence of various structural configurations prior to rolling (i.e. crystallinity, size of spherulites, etc.), a commercially supplied material was selected for use.

\section{EXPERIMENTAL PROCEDURE}

A large sheet ( 4 feet by 8 feet) of high density polyethylene, whose nominal thickness was 0.130 inch, was obtained from Cadillac Plastics in the 
"standard" condition; as such, it was a typical commercial structure with no special processing involved. Numerous strips, about one inch wide by six inches long, were sectioned from the sheet with the six-inch dimension always being parallel to the initial sheet length.

Several of these strips were set aside for future tests in the "as received" condition while the remainder were cold rolled using a two high, sixinch diameter rolling mill. All rolling was performed at room temperature and the sequence of reductions led to similar strain histories. For example, all specimens were first reduced in thickness by an apparent or initial amount of $5 \%$ using exactly the same number of passes and roll settings. A pair of these, hereafter designated as having $5 \%$ apparent cold work, was set aside and the remainder were subjected to increasing amounts of additional reduction in strip thickness. In all, eleven pairs of specimens were produced varying from zero to $50 \%$ apparent cold work in $5 \%$ intervals. The resultant morphology of each cold rolled strip was studied by means of wide-angle X-ray. The diffraction pattern was taken with the strip perpendicular to the beam in the "through" position. These studies were made several weeks after the specimens had been rolled and fully relaxed.

Because of the fairly pronounced time dependent dimensional recovery of most polymers, the thickness of the cold rolled strips was measured at continuous intervals until dimensional stability seemed to exist. In most cases, such measurements were made over the span of a week just to add a time factor of safety.

Strip tensile specimens, having a nominal gage section of $\frac{1}{2}$ inch width by three inch length, were made from the 22 test pieces. In each case, the actual area of the test section was measured and each specimen was subjected to a standard tensile test on a $500 \mathrm{~kg}$ capacity Instron machine. A standard strain gage extensometer was adapted to the gage section and was used to drive the strip recorder in order to produce a load-extension curve. One full group of eleven specimens was loaded at a crosshead speed of $0.2 \mathrm{~cm} / \mathrm{min}$ while the second group was tested at a speed of $2.0 \mathrm{~cm} / \mathrm{min}$; all tests were conducted at about $75^{\circ} \mathrm{F}$. For each test, the extensometer was removed shortly after the maximum load was reached since the subsequent deformation was non-uniform. After the neck had fully developed and started to propagate, further data were obtained by recording a specific load and the corresponding minimum area in the neck region; the latter was found through direct measurement using micrometers.

\section{EXPERIMENTAL RESULTS}

The apparent percent cold work and percent reduction in thickness are for practical purposes equivalent in this study since changes in strip width during rolling were minimal. Knowing the roll gap, or by measuring the strip thickness as it was emerging from the rolls, provided the "apparent" percent cold work. After a rolled strip had "fully" recovered as explained in the previous section, the "actual" percent cold work was found; this was always less than the apparent amount since the thickness in-

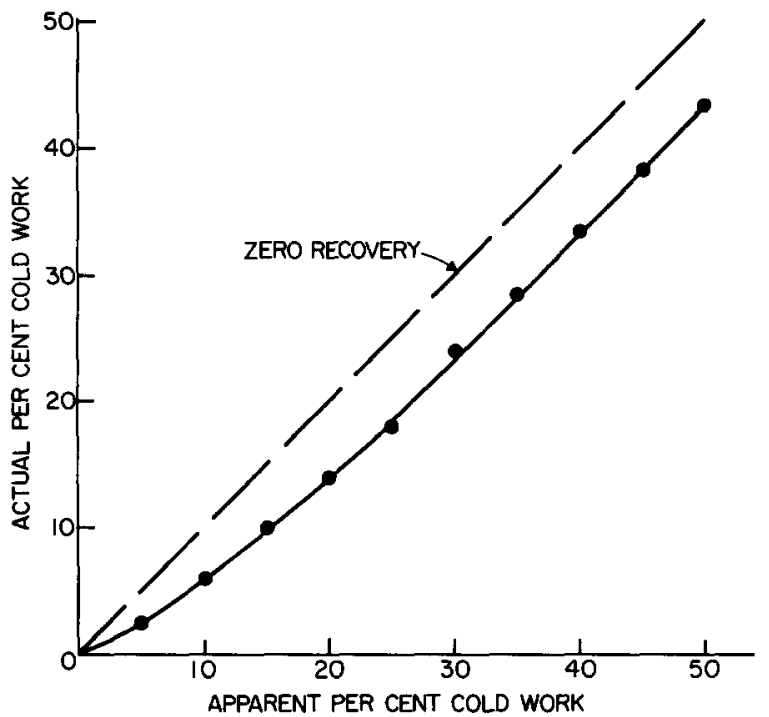

Fig. 1. Comparison of actual vs. apparent per cent cold work of high density polyethylene.

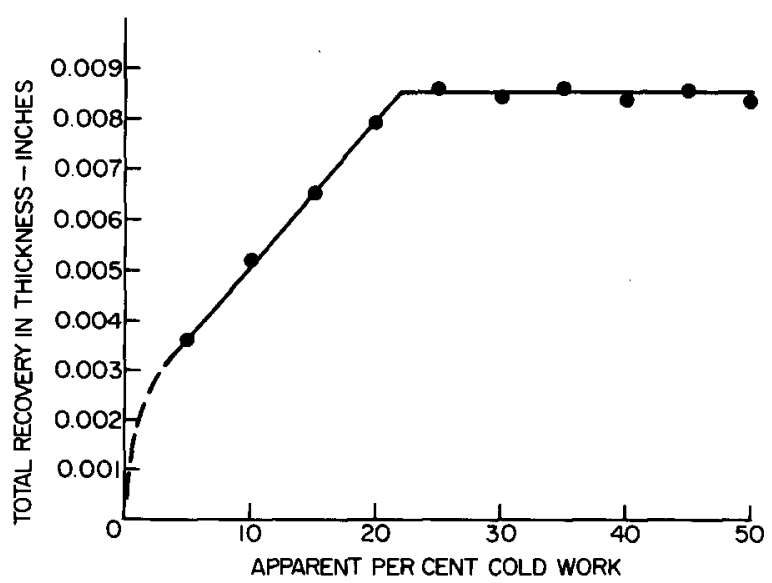

Fig. 2. Thickness recovery after one week as a function of apparent cold work. 


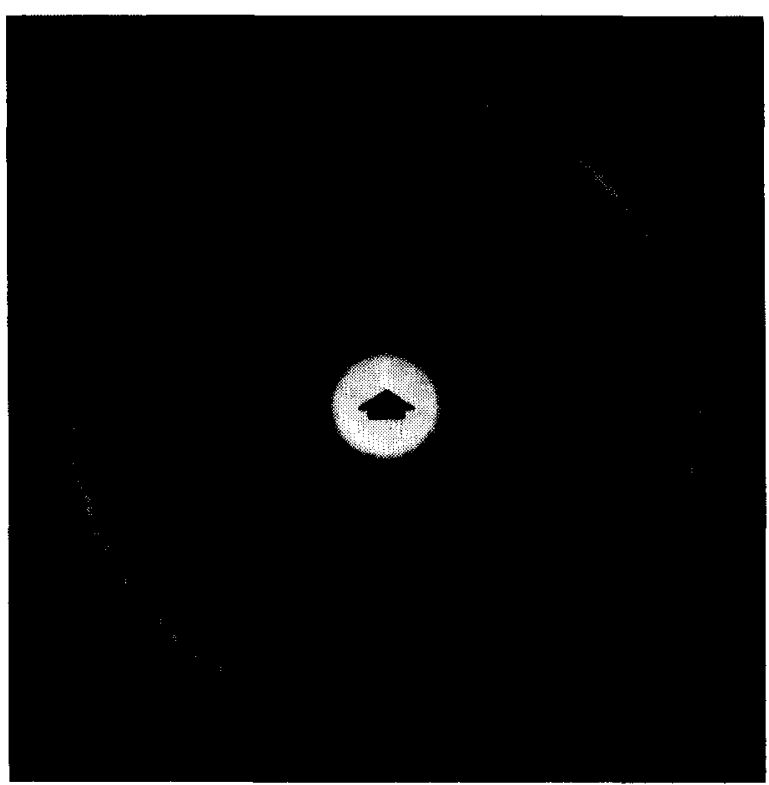

(a)

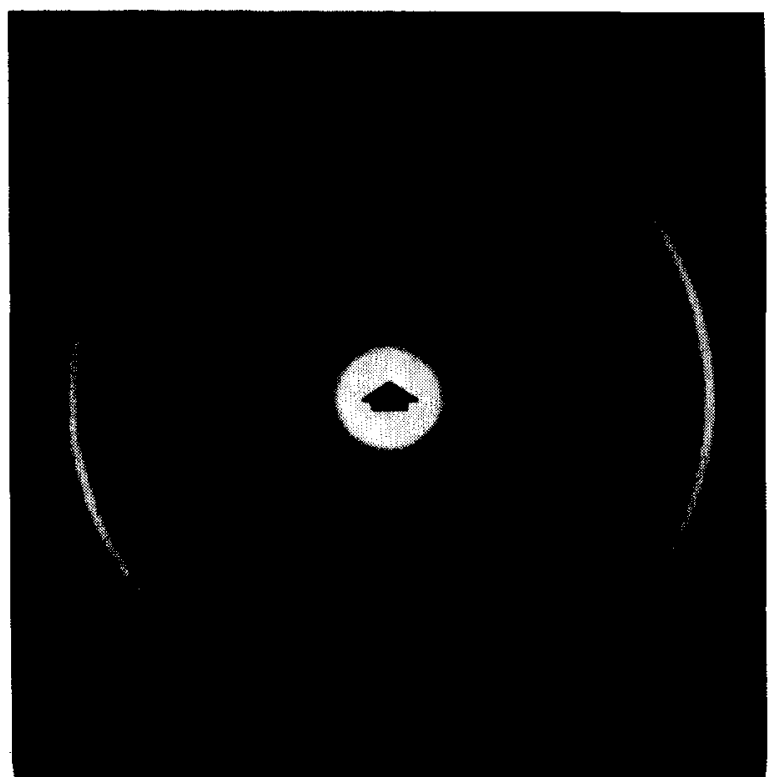

(c)

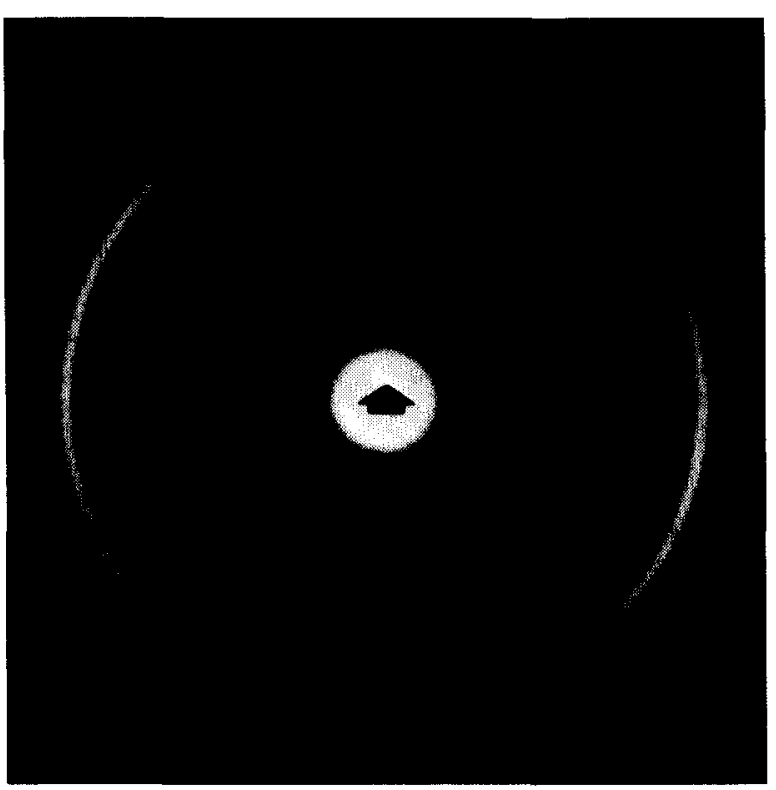

(b)

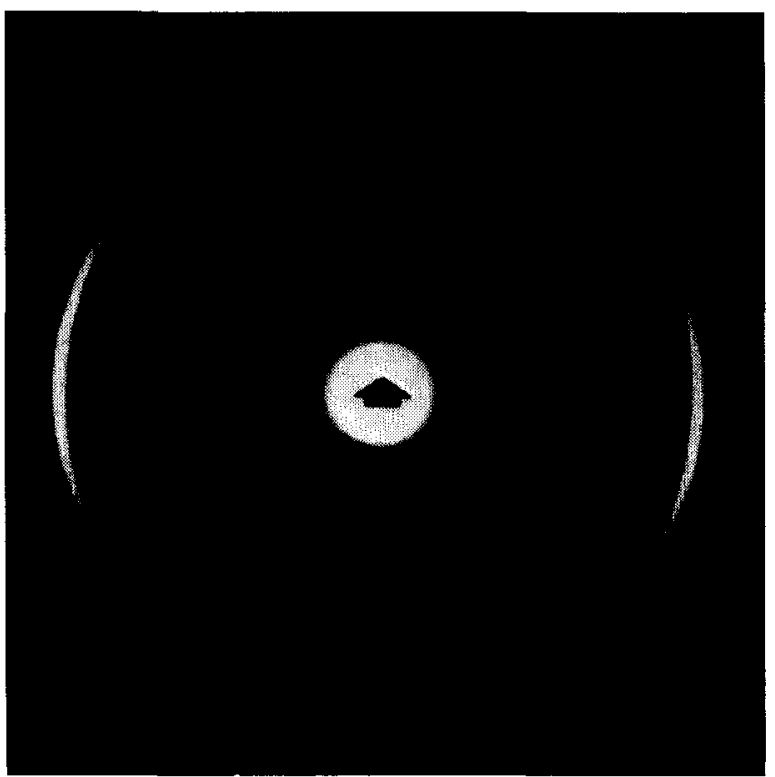

(d)

Fig. 3. X-Ray diffraction patterns of cold rolled high density polyethylene. a, $20 \%$; b, $25 \%$; c, $30 \%$, d, $45 \%$.

creased upon recovery. Figures 1 and 2 show these results plotted in different ways. The former shows a percentage comparison while the latter indicates the actual total recovery in dimension versus apparent percent cold work. Apparently, after a certain critical degree of cold rolling (20 to $25 \%$ in this study), the total recovery is relatively constant after 72 hours. This is quite obvious in Fig. 2 and for the roll diameter-initial thickness combination employed in this study, this value is about $0.0085 \mathrm{inch}$.
Note that Fig. 1 shows the same result but in a less obvious manner; there, a definite change in slope may be seen. After $20-25 \%$ cold work, the succeeding points fall on a line that is parallel to the $45^{\circ}$ line indicated as zero recovery.

A series of pictures taken from some of the X-ray diffraction studies are shown in Fig. 3. These pictures correspond to sample strips that had 20 , 25,30 and $45 \%$ apparent cold work. The X-ray results indicated that there is little or no "perma- 


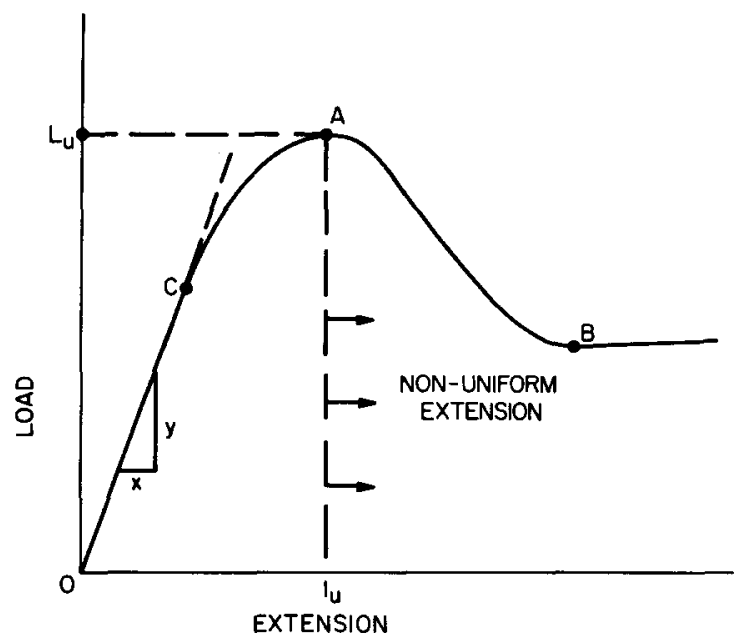

Fig. 4. Descriptive load-extension plot for polyethylene.

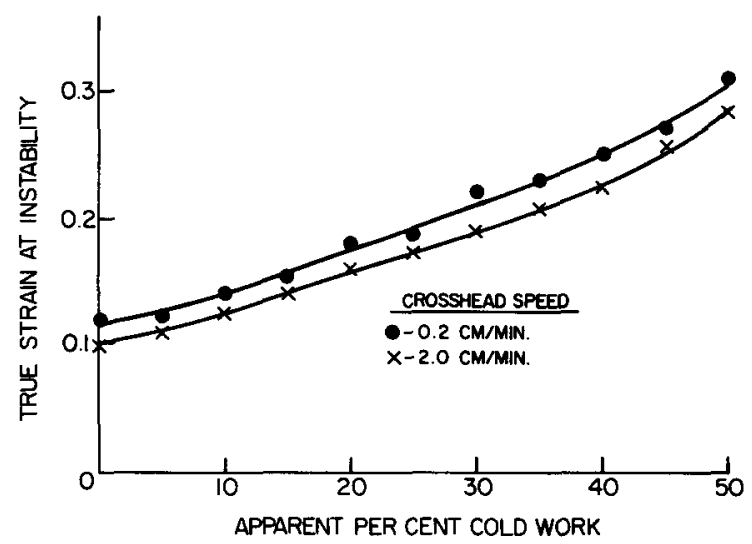

Fig. 5. Effect of cold work on the true strain at tensile instability for two strain rates.

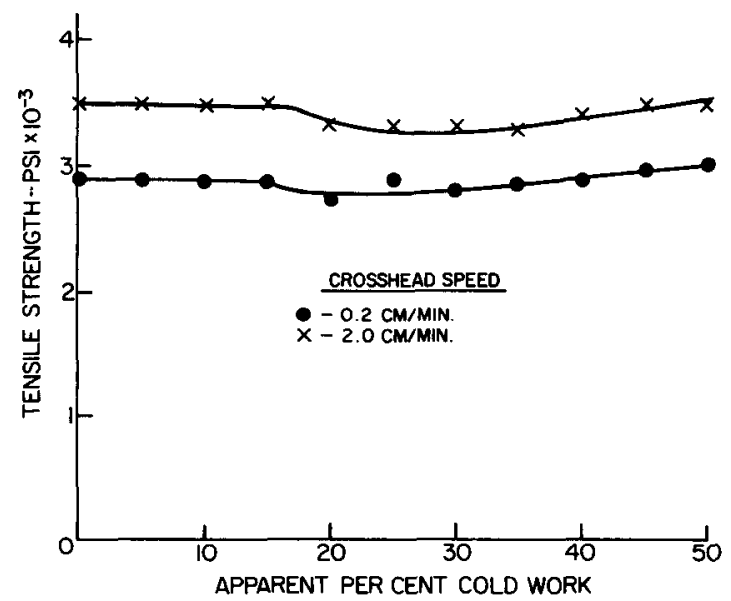

Fig. 6. Effect of cold work on tensile strength for two strain rates. nent" change in samples that had been cold rolled less than $20 \%$ (Fig. 3a). Beginning at about $25 \%$ apparent cold work, a distinct structural change can be detected as judged by the diffraction patterns which show a slight $c$-axis orientation in the rolled direction; the c-axis orientation increases with increasing cold work (Figs. 3b, c and d).

The findings from the tensile tests will be most clear if reference is first made to Fig. 4; this is a qualitative, descriptive plot of the load-extension behavior of the test material employed here. Point A designates the onset of tensile instability and non-uniform deformation (necking) in the gage section. The load, corresponding to the onset of instability, $L_{\mathbf{u}}$, if divided by the original area of the gage section simply defines the'tensile strength, $S_{u}$, of the material. In numerous publications this has also been called a yield point which would be reasonable where it occurred at very small strain values. However, where this point occurs at relatively large strain values, such a "yield" point is questionable. If one considers the traditional definition of macroscopic yielding, there have been relatively few efforts $^{11-13}$ made in regard to a yield criterion for polymeric solids. As mentioned by Brown ${ }^{14}$ there is far from universal agreement on this matter; one might for example expect "yielding" to occur at a load indicated by point $\mathrm{C}$ which is not usually coincident with the maximum load at $\mathrm{A}$. In the test gage section, uniform elongation and reduction in area continue up to point $\mathrm{A}$ and the limit of such deformation can be readily defined in terms of the "true strain at ultimate load." As described elsewhere ${ }^{15}$ this is the natural logarithm of the ratio of the gage length at ultimate load to the initial gage length.

Figure 5 shows that the onset of necking is delayed to greater strain as the degree of cold rolling is increased. A paraphrase is that uniform tensile stretching can be extended by initially cold rolling the piece to be stretched. This idea has been earlier put forth in a statement ${ }^{4}$ where it was correctly pointed out that prior cold rolling eventually eliminates the whitening that accompanies the neck propagation of many polymers and would be advantageous for subsequent deep drawing operations. From Fig. 5 one can also see that increased crosshead speed (analogous to higher strain rates) tends to offset the effect of neck delay caused by cold rolling. This could be an important consideration in the cold deformation of polymers using processes that involve substantially higher strain rates than those 
in evidence here. It has been shown ${ }^{16}$ that strain rates in commercial forming operations are much greater than those employed in quasi-static tests.

The effect of cold rolling on tensile strength, $S_{u}$, is shown in Fig. 6; again the influence of strain rate is indicated. One can see that other factors being equal, higher strain rates give higher apparent strength. This has long been known for many metallic solids, although significant differences occur with smaller changes in strain rate where polymers are involved. It can also be seen in Fig. 6 that changes in tensile strength are small over the range of cold work used but there does appear to be a drop in strength up to about 20 to $25 \%$ cold work. These results are in general agreement with previous findings ${ }^{4}$, but in direct contradiction to others ${ }^{3,10}$. It is probable that this disagreement results because of different uses of the word "strength".

In Fig. 7, three true stress-true strain curves, for each of the two crosshead speeds, are shown. For all individual tests, the data are plotted only to

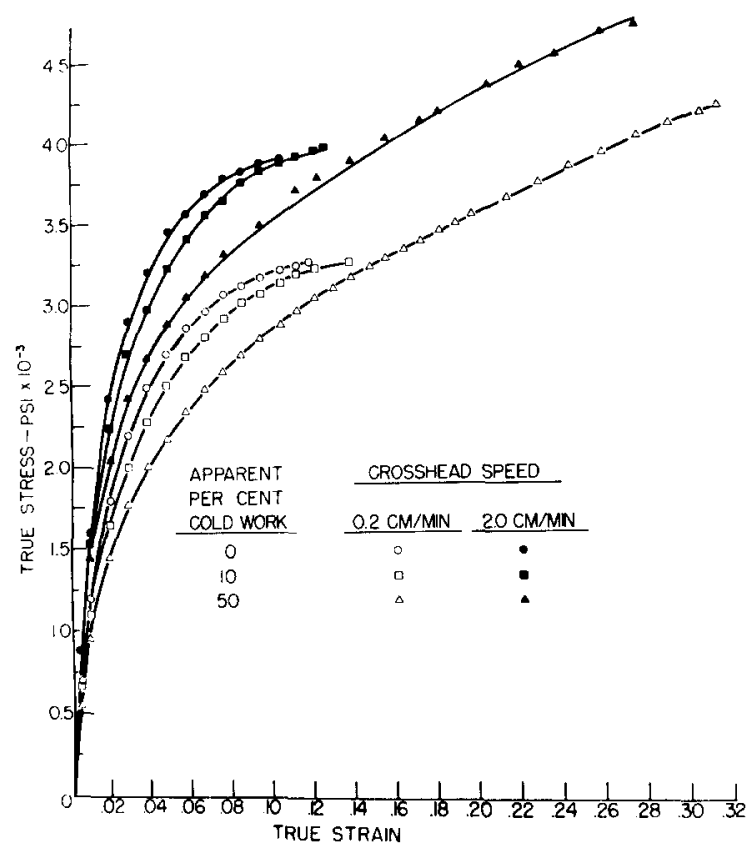

Fig. 7. Typical true stress-true strain behavior of polyethylene cold rolled to different amounts and tested at two strain rates.

strains at instability. Attempts to plot all eleven sets of data for each crosshead speed led to complete loss of clarity; however, each group of eleven curves would fall within the extremes shown. It should be noted that the specimen with no cold work is stronger at the low strain levels but reaches a state of non-uniform elongation at lower strain levels. This trend prevailed consistently for both groups of eleven curves. As a group, the curves obtained with

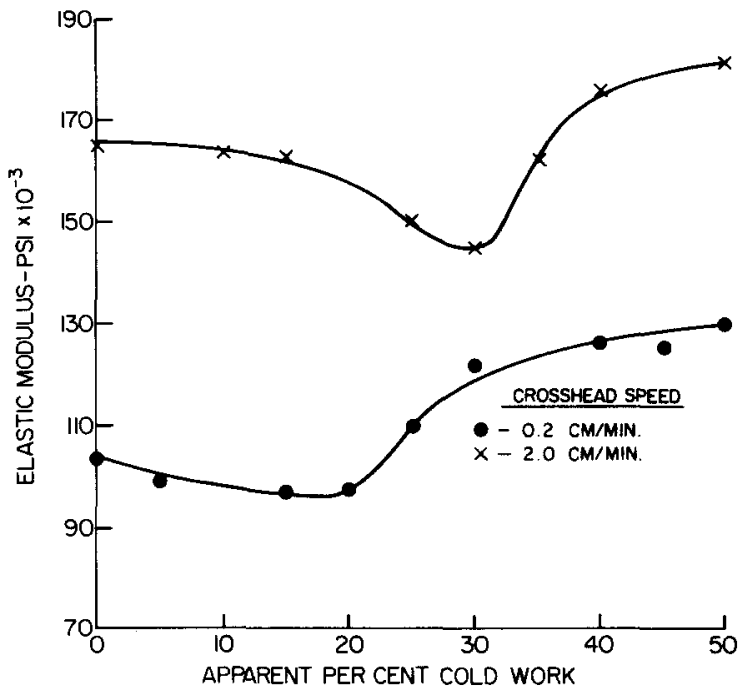

Fig. 8. Effect of cold work on elastic modulus for two strain rates.

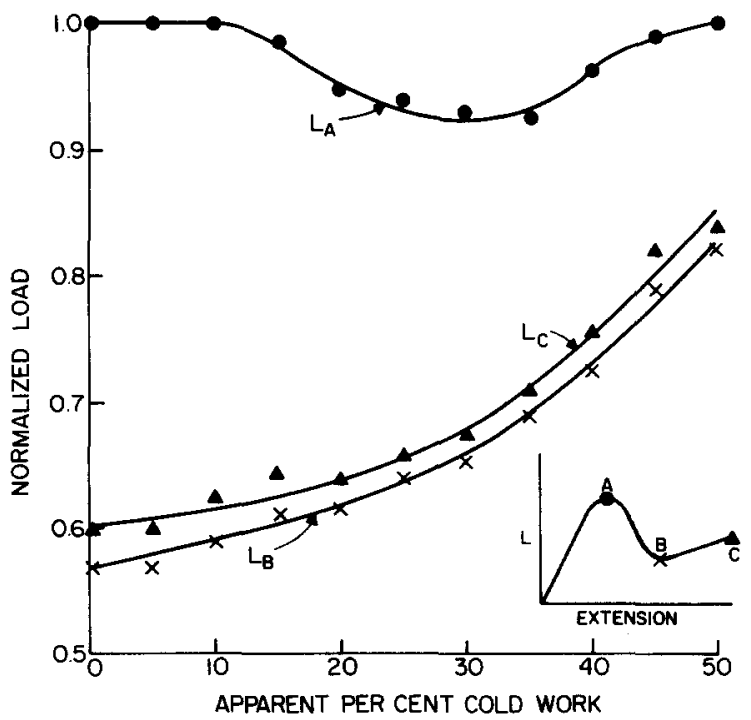

Fig. 9. Effect of cold work on various tensile load ratios to illustrate the decreasing tendency in load drop from the instability point.

higher rates are displaced upward which is similar to the findings in Fig. 6.

Values of the elastic modulus were obtained using the initial straight line portion of the load extension curves defined by $\mathrm{x}$ and $\mathrm{y}$ in Fig. 4. Appropriate 
conversions to stress and strain were made; from these the elastic modulus was determined. All meaningful results are shown in Fig. 8 where again there tends to be a decrease up to about $25 \%$ cold work. This suggests a possible break up of the rigid spherulitic structures without observable chain orientations between zero and $25 \%$ cold work (see Fig. 3). The rise in the elastic modulus in the region of $30 \%$ cold work can be attributed to the increasing $\mathrm{c}$ axis orientation with increasing cold work.

As mentioned earlier, the tendency towards neck propagation can be retarded, and the onset of whitening can be eliminated with a sufficient amount of initial cold rolling. For polyethylene rolled to a maximum of $50 \%$ cold work, neck formation and propagation were still in evidence, and the elimination of what has been called the "yield drop" elsewhere ${ }^{3}$ was not in evidence. Figure 9 shows the values of "normalized" loads at points $\mathrm{A}, \mathrm{B}$ and $\mathrm{C}$ of the insert sketch. There, the maximum load for the unrolled material was taken as unity and all other loads of interest were divided by that base value. Two points are worth noting. First, the curve designated as $L_{A}$ is basically a duplicate of the upper curve on Fig. 6 where each "tensile strength" was converted to a maximum load. Secondly, the load drop from point A to point B shows a general decrease with increasing cold work. Apparently, the elimination of such a load drop occurs with cold work of less than $50 \%$ for other polymers ${ }^{4}$.

\section{REFERENCES}

1 J. G. Williams and H. Ford, J. Mech. Eng. Sci., 6 (1964) 405.

2 J. G. Williams and H. Ford, J. Mech. Eng. Sci., 9 (1967) 362.

3 L. J. Broutman and S. Kalpakjian, SPE J., 25 (1969) 46.

4 L. J. Broutman and R. S. Patil, Soc. Plast. Engrs., 28th Ann. Tech. Conf., New York, 1970, p. 20.

5 A. Buckley and H. A. Long, Polymer Eng. Sci., 9 (1969) 664.

6 T. Hinton and J. G. Rider, J. Appl. Phys., 39 (1968) 4932.

$7 \mathrm{~K}$. Imada, T. Yamamoto, K. Shigematsu and M. Takayangi, J. Mater. Sci., 6 (1971) 537.

8 A. J. Owen and I. M. Ward, J. Mater. Sci., 6 (1971) 485.

9 G. Meinel and A. Peterlin, J. Polymer Sci., A-2, 9 (1971) 67.

\section{CONCLUSIONS}

On the basis of the results of this study using high density polyethylene, the following conclusions are drawn:

1. Beyond a particular amount of deformation of strip by cold rolling, the total recovery of dimensional thickness is relatively constant.

2. Cold rolling has seemingly little effect on increasing the tensile strength. This is completely opposite to the behavior of ductile metals where cold working causes a continuous increase in tensile strength.

3. The onset of necking or tensile instability is delayed if cold rolling precedes the application of uniaxial tensile stress; there seems to be a consistent trend in this regard. Again this behavior is directly opposite to that of ductile metals where prior cold working causes tensile instability to occur at lower levels of tensile strain. This is probably due to the vastly different structures existing before and after permanent deformation ${ }^{17}$.

4. Other factors being equal, higher strain rates tend to increase the resistance to tensile deformation as judged from strength measurements but tend to cause tensile instability to occur at lower strain levels. These results are similar in nature to those found with ductile metals.

5. The elastic modulus appears to decrease up to a critical level of cold work after which it begins to increase. In general, ductile metals show little change in this regard.

10 P. H. Rothschild and B. Maxwell, J. Appl. Polymer Sci., V, 16 (1961) 311.

11 S. S. Sternstein, L. Ongchin and A. Silverman, Appl. Polymer Symp., 7 (1968) 175.

12 S. S. Sternstein and L. Ongchin, Am. Chem. Soc., Polymer Prep., 1969, 1117.

13 W. Whitney and R. D. Andrews, J. Polymer Sci., C, 16 (1967) 2981.

14 N. Brown, Mater. Sci. Eng., 8 (1971) 69.

15 R. M. Caddell and R. Sowerby, Bull. Mech. Eng. Educ., 8 (1969) 31.

16 A. G. Atkins, J. Inst. Metals, 97 (1969) 289.

17 G. S. Y. Yeh and P. H. Geil, J. Macromol. Sci., B2 (1968) 29. 
Comportement en traction du polyéthylène de haute densité après un laminage à froid

Par laminage à froid, on a préparé une série d'éprouvettes de polyéthylène de haute densité écrouies de 0 à $50 \%$. Dans les éprouvettes écrouies de plus de $20 \%$, la restauration après laminage produit une variation d'épaisseur relativement constante en valeur absolue. Les études par diffraction des rayons $X$ révèlent que la structure initiale des éprouvettes écrouies de plus de $20 \%$ a subi des changements notables et que l'axe $c$ tend de plus en plus à s'orienter parallèlement à la direction de laminage, quand le taux d'écrouissage augmente.

Le comportement en traction, à deux vitesses différentes, a toujours été étudié avec des éprouvettes totalement restaurées. La partie initiale des courbes de traction rationnelles change lorsque le taux de laminage à froid préalable augmente; ceci se traduit par des valeurs différentes du module élastique. Celui-ci passe par un minimum pour un taux de laminage voisin de $25 \%$.

L'instabilité en traction (striction) se produit plus tard lorsque le taux de laminage à froid préalable augmente, mais l'écrouissage ne produit que de faibles variations de résistance. Ces résultats s'appliquent aux deux vitesses de déformation. Si l'on compare des éprouvettes dans des états "structuraux" analogues (par exemple après $15 \%$ d'écrouissage à froid), on constate qu'aux vitesses de déformation élevées correspondent une résistance plus grande et un allongement réparti plus faible.

Le comportement du polymère étudié est comparé de manière qualitative avec celui des métaux ductiles.
Zum Zugverhalten von kaltverformtem Polyäthylen hoher Dichte

Aus Polyäthylen hoher Dichte wurde durch Walzen bis zu $50 \%$ eine Serie von Proben mit verschiedener Kaltverformung hergestellt. Bei allen stärker als $20 \%$ gewalzten Proben war die absolute Dickenerholung relativ konstant. Röntgenbeugungsexperimente zeigten, daß in den stärker als $20 \%$ kaltverformten Proben beträchtliche Änderungen der Ausgangsstruktur auftraten und da $B$ mit zunehmender Kaltverformung die $c$-Achsenorientierung häufiger auftrat.

An vollständig erholten Proben wurde das Zugverhalten bei zwei verschiedenen Dehngeschwindigkeiten untersucht. Der Anfangsteil der SpannungsDehnungs-Kurve ändert sich mit zunehmender Kaltverformung der Ausgangsproben. Das zeigt sich in den verschiedenen Werten des Elastizitätsmoduls, der für das $25 \%$ kaltverformte Material ein Minimum aufweist.

Zuginstabilitäten und die Bildung von Einschnürungen werden durch stärkere Vorverformung verzögert; die Zugfestigkeit wird von der vorangegangenen Kaltverformung jedoch nur wenig beeinflußt. Diese Beobachtungen gelten für beide Dehngeschwindigkeiten. Für Proben mit ähnlichen "Struktureigenschaften", z.B. für $15 \%$ kaltverformte Proben, gilt, daß bei der höheren Dehngeschwindigkeit eine größere Festigkeit und eine kleinere Dehnung bei Auftreten der Instabilität beobachtet wird.

Das Verhalten dieses Polymers wird qualitativ mit dem duktiler Metalle verglichen. 